\title{
Data report: geochemistry of volcaniclastic sediments drilled during IODP Expedition 310 in Tahiti'
}

\author{
Paterno Castillo 2
}

\section{Chapter contents}

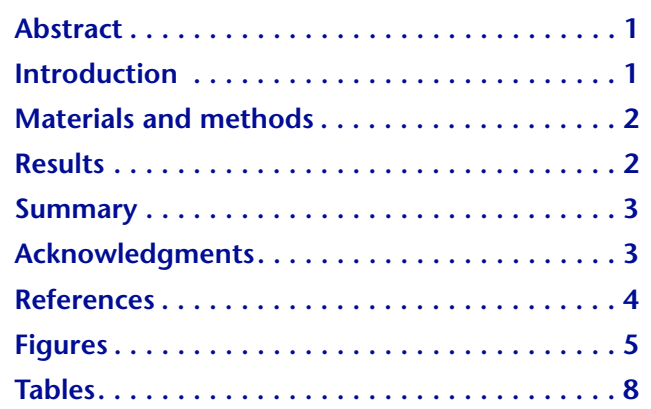

${ }^{1}$ Castillo, P., 2009. Data report: geochemistry of volcaniclastic sediments drilled during IODP Expedition 310 in Tahiti. In Camoin, G.F., Iryu, Y., Mclnroy, D.B., and the Expedition 310 Scientists, Proc. IODP, 310: Washington, DC (Integrated Ocean Drilling Program Management International, Inc.). doi:10.2204/iodp.proc.310.202.2009

${ }^{2}$ Scripps Institution of Oceanography, University of California, San Diego, La Jolla CA 92093-0212, USA.pcastillo@ucsd.edu

\begin{abstract}
Variable amounts of volcaniclastic sediments are present in the carbonate rocks that were drilled in the Tiarei, Maraa, and Faaa areas seaward of the modern fringing reefs in Tahiti during Integrated Ocean Drilling Program Expedition 310. Twenty-four representative samples of volcaniclastic sediments from the Tiarei area, ranging in grain size from clay to boulder, were analyzed for major and trace element contents. The samples are variably altered, but the least altered ones are compositionally similar to the igneous rocks of the island of Tahiti. Four samples that were dated by the ${ }^{40} \mathrm{Ar} /{ }^{39} \mathrm{Ar}$ dating method range in age from 0.3 to $0.7 \mathrm{Ma}$. Age data combined with geochemical data indicate that the bulk of the volcaniclastic sediments originated from the younger $(\leq 1.3$ Ma) rock series in Tahiti. Most of the fine-grained samples were also analyzed for their total, organic, and inorganic carbon contents; the samples show a general decrease in carbon contents with depth.
\end{abstract}

\section{Introduction}

The island of Tahiti, at $17^{\circ} 50^{\prime} \mathrm{S}$ and $149^{\circ} 20^{\prime} \mathrm{W}$, is a volcanic island belonging to a group of Neogene-Quaternary linear volcanic chains in French Polynesia, south-central Pacific. The drowned Pleistocene to Holocene reef terraces seaward of the modern fringing reefs in Tahiti were drilled during Integrated Ocean Drilling Program (IODP) Expedition 310 in order to study environmental change, including sea level rise following the Last Glacial Maximum (LGM) (Camoin et al., 2007; see the "Expedition 310 summary" chapter). A total of $632 \mathrm{~m}$ of mostly carbonate rocks were cored from several holes in the Tiarei (northern), Maraa (southern), and Faaa (western) drilling areas off the island during Expedition 310. Uncemented to poorly consolidated volcaniclastic sediments were also recovered in all drilling areas, albeit these mainly occur as fine-grained impurities in many of the carbonate rock units and as relatively thin units interbedded with the carbonate rocks. However, a $\sim 36 \mathrm{~m}$ thick sequence of alternating sand, silt, clay, and pebbly/cobbly materials was drilled in the Hole M0008A reference site in the Tiarei area near the mouth of the Papenoo River, the largest drainage system in Tahiti (see the "Tiarei marginal sites: Sites M0008, M0010-M0014, and M0022" chapter). This report presents geochemical and age data 
for the volcaniclastic sediments recovered during Expedition 310 in order to provide background information for future detailed geochemical work on these materials.

\section{Materials and methods}

Fourteen samples from Hole M0008A in the Tiarei area have previously been analyzed for major element contents, except $\mathrm{Na}_{2} \mathrm{O}$, by energy dispersive polarized X-ray fluorescence (XRF) at Bremen University (Germany) (see the "Tiarei marginal sites: Sites M0008, M0010-M0014, and M0022" chapter). The contents of some trace elements, including $\mathrm{Sr}, \mathrm{Ba}, \mathrm{Rb}, \mathrm{Cu}, \mathrm{Ni}$, and $\mathrm{Zn}$, have also been analyzed. The samples include sand-silt-clay mixtures, pebbles, cobbles, and boulders. For this report, $\mathrm{Na}_{2} \mathrm{O}$ contents of the previously analyzed samples were determined by inductively coupled plasma-optical emission spectrometry at the Scripps Institution of Oceanography (SIO), University of California, San Diego (USA). The precision of the $\mathrm{Na}_{2} \mathrm{O}$ analysis based on repeated analyses of the international rock standard $\mathrm{AGV}-1$ is $\leq 3.5 \%$.

Three additional sand-silt samples from Hole M0008A plus two sand samples from Hole M0010A and one sand sample from Hole M0021B (all in the Tiarei area) were analyzed for major elements and trace elements $\mathrm{Ni}, \mathrm{Cr}, \mathrm{Sc}, \mathrm{V}, \mathrm{Ba}, \mathrm{Rb}, \mathrm{Sr}, \mathrm{Zr}, \mathrm{Nb}, \mathrm{Ga}, \mathrm{Cu}$, $\mathrm{Zn}, \mathrm{Pb}, \mathrm{La}, \mathrm{Ce}, \mathrm{Th}, \mathrm{Nd}$, and $\mathrm{U}$ by XRF at the GeoAnalytical Laboratory at Washington State University (WSU) (USA). Information on methods, precision, and accuracy of the XRF analysis at WSU are available at www.sees.wsu.edu/Geolab/index.html. All samples previously and newly analyzed for major elements were analyzed for loss on ignition (LOI) values at SIO and WSU, respectively.

All the above samples plus four small amounts of sand-silt samples from Hole M0021B were also analyzed for trace elements, including $\mathrm{Rb}, \mathrm{Sr}, \mathrm{Y}, \mathrm{Ba}, \mathrm{U}$, $\mathrm{Th}$, and $\mathrm{Pb}$ and the rare earth elements (REE) $\mathrm{La}, \mathrm{Ce}$, Pr, Nd, Sm, Eu, Tb, Dy, Ho, Er, Tm, Yb, and Lu by high-resolution inductively coupled plasma-mass spectrometry (ICP-MS) at SIO. Samples were prepared by digesting $25 \mathrm{mg}$ of powder using the HF$\mathrm{HNO}_{3}$ method described by Janney and Castillo (1996). Digested samples were diluted $4000 \times$ in a solution containing $2.5 \mathrm{wt} \%$ nitric acid and $1 \mathrm{ppb}$ In as an internal standard. Time- and mass-dependent instrumental drift was corrected for by applying a mass-interpolated internal standard correction and correcting measured sample concentrations using values of a well-analyzed in-house mid-ocean-ridge basalt (MORB) standard analyzed repeatedly throughout each run. Duplicate analyses of stan- dards and a number of unknowns were conducted, each analysis in a different run. Reproducibility was generally high $(\leq 3 \%)$, except for elements that have low $(<0.2 \mathrm{ppm})$ concentrations.

Four fresh-looking coarse-grained (pebble to boulder size) volcaniclasts were dated by ${ }^{40} \mathrm{Ar} /{ }^{39} \mathrm{Ar}$ dating at the Noble Gas Mass Spectrometry Laboratory at Oregon State University (OSU) (USA). These include two large boulders that were originally suspected as parts of a pre-LGM lava flow in the upper section of Hole M0008A (see the "Tiarei marginal sites: Sites M0008, M0010-M0014, and M0022" chapter), a pebble in the lower section of Hole M0008A, and a pebble in Hole M0010A. Information on methods, precision, and accuracy of the ${ }^{40} \mathrm{Ar} /{ }^{39} \mathrm{Ar}$ dating method at OSU are similar to those described in Koppers et al. (2004) and are available at www.coas.oregonstate.edu/research/mgg/chronology.html.

Almost all fine-grained (sand, silt, and clay sized) volcaniclastics were also analyzed for total and inorganic carbon contents (organic carbon contents were calculated by mass balance) at SIO. Total carbon content was determined by combustion with $\mathrm{O}_{2}$ using a Costech elemental analyzer in $\mathrm{CHN}$ mode. Inorganic carbon content was determined by reaction with phosphoric acid and measurement with a ThermoFisher Delta XP plus isotope ratio mass spectrometer with associated gas bench. Accuracy for total carbon measurement was $1 \%$, whereas accuracy for inorganic measurement was $2 \%$.

\section{Results}

Save for the highly calcareous volcanic sand Sample 310-M0021B-18R-1, 55-58 cm, anhydrous bulk rock analyses mainly plot in the basalt field (Table T1; Fig. F1) and overlap with the magmatic lineages identified in Tahiti (e.g., Duncan et al., 1987; Cheng et al., 1993). The majority of the volcaniclastic sediments are alkalic basalts that belong to the Series B magmatic lineage $(0.6-1.3 \mathrm{Ma})$. It is important to note, however, that the samples are variably altered and therefore have low total weights of all major oxides (see the "Expedition 310 summary" chapter). Indeed, the samples have a large range of LOI values (Table T1), which are generally observed to positively correlate with degrees of alteration. However, although the fine-grained volcaniclastics unsurprisingly have higher LOI values (6-37 wt\%) than the coarse-grained volcaniclasts $(2-10 \mathrm{wt} \%)$, there appears to be no systematic compositional difference between the two groups in Figure F1 except that the fine-grained volcaniclastics span a larger range of $\mathrm{SiO}_{2}$ values. Moreover, the anhydrous oxides of the samples generally show coherent trends when plot- 
ted against $\mathrm{MgO}$ or $\mathrm{TiO}_{2}$ contents (not shown). Therefore, although samples with high LOI values are most probably the most altered, it is difficult to constrain the effect of alteration on their major element composition based on LOI values alone. It is only after looking at their trace element contents that a better picture of the alteration effect on the samples emerged, as described below.

Volcaniclastic sediments have variable trace element contents, but as a whole they are generally enriched in highly incompatible relative to less incompatible trace elements (Fig. F2) as indicated by their $\mathrm{La} / \mathrm{Sm}_{\mathrm{N}}$ values of $>1$ (Table T1). Some of the samples, though, have uncharacteristically low concentrations of some incompatible trace elements such as $\mathrm{Rb}$, Th, and REE, particularly the heavy ones, some of which are below the detection limit of the ICP-MS used (indicated by dashes in Table T1). These samples also have a saw-toothed pattern in spider diagrams (not shown). This trace element characteristic is shown by both fine- and coarse-grained volcaniclastics and is most probably due to alteration, but available LOI data again show that coarse-grained volcaniclasts with unusually low incompatible trace element contents do not systematically have higher LOI values than volcaniclasts with higher incompatible trace element contents. Among the fine-grained volcaniclastics, however, the low incompatible trace element content is definitely due to the dilution of the volcaniclasts by calcareous components as illustrated by the aforementioned highly calcareous sand Sample 310-M0021B-18R-1, 55-58 cm. More importantly, most of the incompatible trace elements generally correlate inversely with inorganic carbon contents, except Sr, which generally shows positive correlation (not shown). New data for the less altered samples confirm the general increase in highly incompatible elements with depth in Hole M0008A (Fig. F3; see the "Tiarei marginal sites: Sites M0008, M0010-M0014, and M0022" chapter).

One of the objectives of carbon content analysis (Table T1) is for possible future paleoenvironmental reconstructions such as carbon storage on exposed shelves during the LGM (e.g., Sifeddine et al., 2004; Montenegro et al., 2006). In Tahiti, the presence of a shoreline is suggested by a gray to orange color transition in the volcaniclastic sediments in Sample 310M0008A-8R-1, $100 \mathrm{~cm}$ (see the "Tiarei marginal sites: Sites M0008, M0010-M0014, and M0022" chapter). A deep brown paleosoil horizon containing fine plant roots occurs directly below the color transition. In Hole M0008A, total carbon contents of the fine-grained volcaniclastics range from $\sim 0.1$ to 1.4 $\mathrm{wt} \%$ above the transition and are $<0.1 \mathrm{wt} \%$ below it (Table T1). Thus it would be difficult to investigate in detail the elemental and isotopic composition of organic carbon in the purported shoreline (Fig. F3). Another, though less distinct, gray-orange color transition occurs in the bindstone unit in Section 310-M0021B-19R-1 (see the "Tiarei outer ridge: Sites M0009, M0021, and M0024-M0026" chapter), which suggests another possible shoreline farther offshore in the Tiarei area. Here total carbon contents of the fine-grained volcaniclastics range from 6.0 to $11.5 \mathrm{wt} \%$ above the color transition and from 3.8 to $4.2 \mathrm{wt} \%$ below it (Table T1). However, organic carbon contents of the brown fine-grained volcaniclasts are only $\leq 0.1 \mathrm{wt} \%$, and thus it would also be difficult to investigate the elemental and isotopic composition of organic carbon in the volcaniclastic sediments below the color transition at this site.

The four coarse-grained volcaniclasts analyzed by the ${ }^{40} \mathrm{Ar} /{ }^{39} \mathrm{Ar}$ dating method range in age from 0.3 to $0.7 \mathrm{Ma}$ (Table T2). Although the two boulders in Hole M0008A have the same age, they are relatively old $(\sim 0.7 \mathrm{Ma})$ to be a lava flow that covered the LGM shoreline. Moreover, although one of the boulders is highly altered (Table T1), available data suggest that they may have come from two different lava flows (see the "Tiarei marginal sites: Sites M0008, M0010-M0014, and M0022" chapter). In general, the ages of the samples combined with major element data (Fig. F1) suggest that the bulk of the volcaniclastic sediments drilled during Expedition 310 were derived from the younger $(\leq 1.3 \mathrm{Ma})$ rock series in Tahiti.

\section{Summary}

1. The volcaniclastic sediments drilled from offshore Tahiti during Expedition 310 are variably altered.

2. Unsurprisingly, the bulk composition of the least altered volcaniclastic sediments is similar to that of the volcanic and igneous rocks in Tahiti.

3 . The bulk of the volcaniclastic sediments was derived from the younger $(\leq 1.3 \mathrm{Ma})$ alkalic to highly alkalic $(<0.6 \mathrm{Ma})$ rock series in Tahiti.

4. Age data suggest that there is no post-LGM lava flow in the Tiarei area.

5. Total carbon and organic carbon contents are low in the deeper sections of the fine-grained volcaniclastic sediments drilled from offshore Tahiti.

\section{Acknowledgments}

Thanks are due to the Expedition 310 Scientific Party, particularly to the Co-Chief Scientists G. Camoin and Y. Iryu and European Consortium for Ocean 
Research Drilling (ECORD) Science Operator (ESO) Staff Scientist D. McInroy, to the staff of the Bremen Core Repository (Germany), and to G. Fitton for his review. Many thanks also to B. Dennis-Duke for help with the analytical work and to the Noble Gas Mass Spectrometry Laboratory at OSU for the ${ }^{40} \mathrm{Ar} /{ }^{39} \mathrm{Ar}$ age analysis. This research used samples and/or data provided by the Integrated Ocean Drilling Program (IODP). Funding for this research was provided by National Science Foundation/Joint Oceanic Institute JSA22T310A22 to P.C. P.C. is a member of the IODP Expedition 310 Scientific Party.

\section{References}

Camoin, G.F., Iryu, Y., McInroy, D.B, and the IODP Expedition 310 Scientists, 2007. IODP Expedition 310 reconstructs sea level, climatic, and environmental changes in the South Pacific during the last deglaciation. Sci. Drill., 5:4-12. doi:10.2204/iodp.sd.5.01.2007

Duncan, R.A., Fisk, M.R., and Natland, J., 1987. The development of volcanism at Tahiti, French Polynesia. Eos, Trans. Am. Geophys. Union, 68(44):1521. (Abstract)

Cheng, Q.C., Macdougall, J.D., and Lugmair, G.W., 1993. Geochemical studies of Tahiti, Teahitia and Mehetia, Society Island chain. J. Volcanol. Geotherm. Res., 55(12):155-184. doi:10.1016/0377-0273(93)90096-A

Janney, P.E., and Castillo, P.R., 1996. Basalts from the Central Pacific Basin: evidence for the origin of Cretaceous igneous complexes in the Jurassic western Pacific. J. Geophys. Res., 101(B2):2875-2893. doi:10.1029/ 95JB03119

Koppers, A.A.P., Duncan, R.A., and Steinberger, B., 2004. Implications of a nonlinear ${ }^{40} \mathrm{Ar} /{ }^{39} \mathrm{Ar}$ age progression along the Louisville Seamount trail for models of fixed and moving hot spots. Geochem., Geophys., Geosyst., 5(6):Q06L02. doi:10.1029/2003GC000671

Montenegro, A., Eby, M., Kaplan, J.O., Meissner, K.J., and Weaver, A.J., 2006. Carbon storage on exposed continental shelves during the glacial-interglacial transition. Geophys. Res. Lett., 33(8):L08703. doi:10.1029/ 2005GL025480

Sifeddine, A., Wirrmann, D., Albuquerque, A.L.S., Turcq, B., Cordeiro, R.C., Gurgel, M.H.C., and Abrão, J.J., 2004. Bulk composition of sedimentary organic matter used in palaeoenvironmental reconstructions: examples from the tropical belt of South America and Africa. Palaeogeogr., Palaeoclimatol., Palaeoecol., 214(1-2):41-53. doi:10.1016/S0031-0182(04)00322-0

Sun, S.-S., and McDonough, W.F., 1989. Chemical and isotopic systematics of oceanic basalts: implications for mantle composition and processes. In Saunders, A.D., and Norry, M.J. (Eds.), Magmatism in the Ocean Basins. Geol. Soc. Spec. Publ., 42(1):313-345. doi:10.1144/ GSL.SP.1989.042.01.19

Initial receipt: 18 August 2008

Acceptance: 15 May 2009

Publication: 14 July 2009

MS 310-202 
Figure F1. Diagram of total alkalis vs. silica, recalculated on a volatile-free basis, for volcaniclastic sediments drilled in the Tiarei area in Tahiti. Solid circles = fine-grained volcaniclastic sediments, open triangles $=$ more altered coarse-grained volcaniclast samples, solid triangles $=$ less altered coarse-grained volcaniclast samples (high degree of alteration based on unusually very low incompatible trace element content). A, B, and C fields = magmatic lineages identified in Tahiti (e.g., Duncan et al., 1987; Cheng et al., 1993).

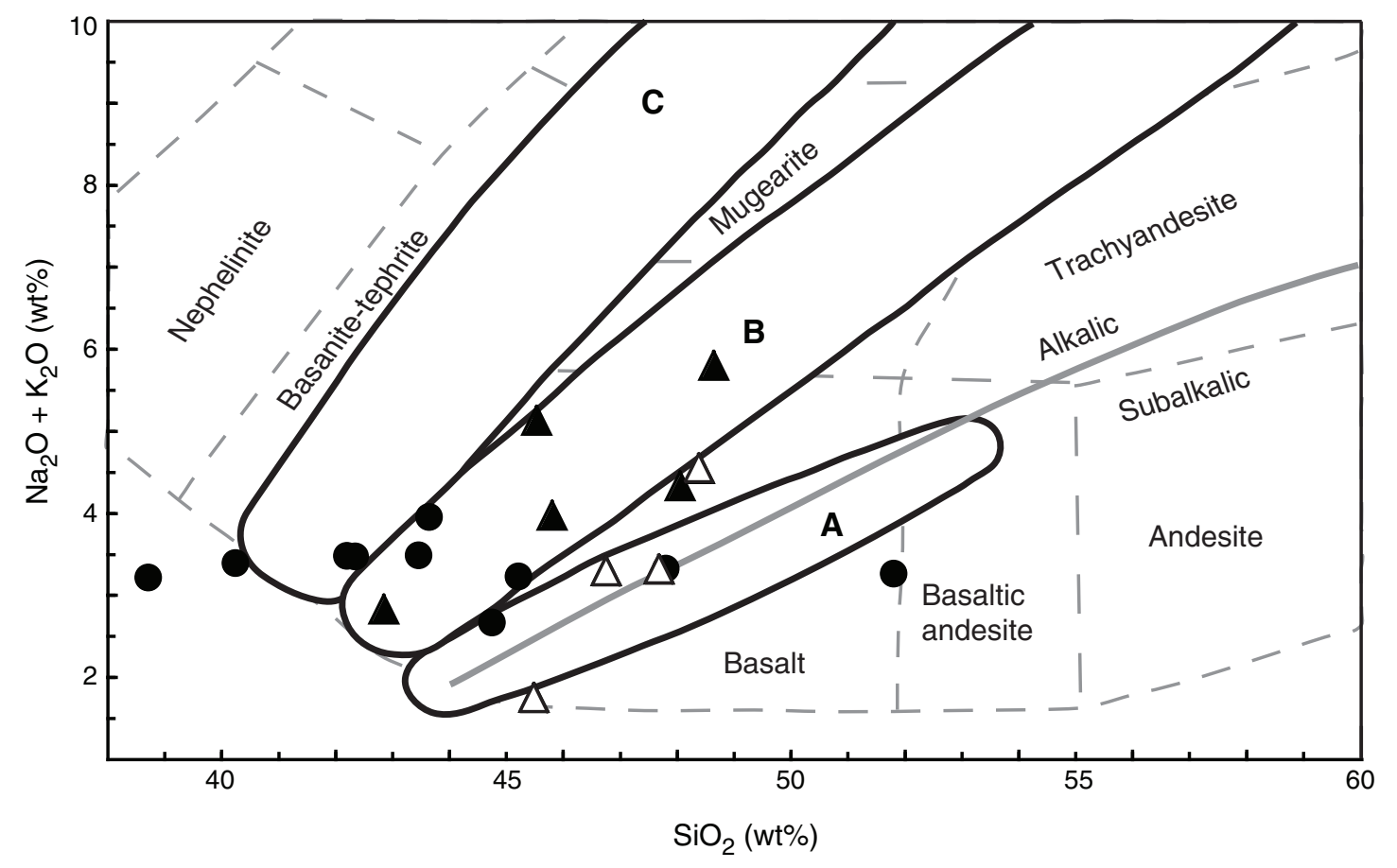


Figure F2. Primitive mantle-normalized incompatible trace element concentrations of the least-altered volcaniclastic sediments drilled from Tahiti. Solid triangles = coarse-grained volcaniclast samples. Gray lines enclose the field for Tahiti igneous rocks compiled in the GEOROC database (georoc.mpch-mainz.gwdg.de/georoc/ Entry.html). Primitive mantle normalizing values are from Sun and McDonough (1989).

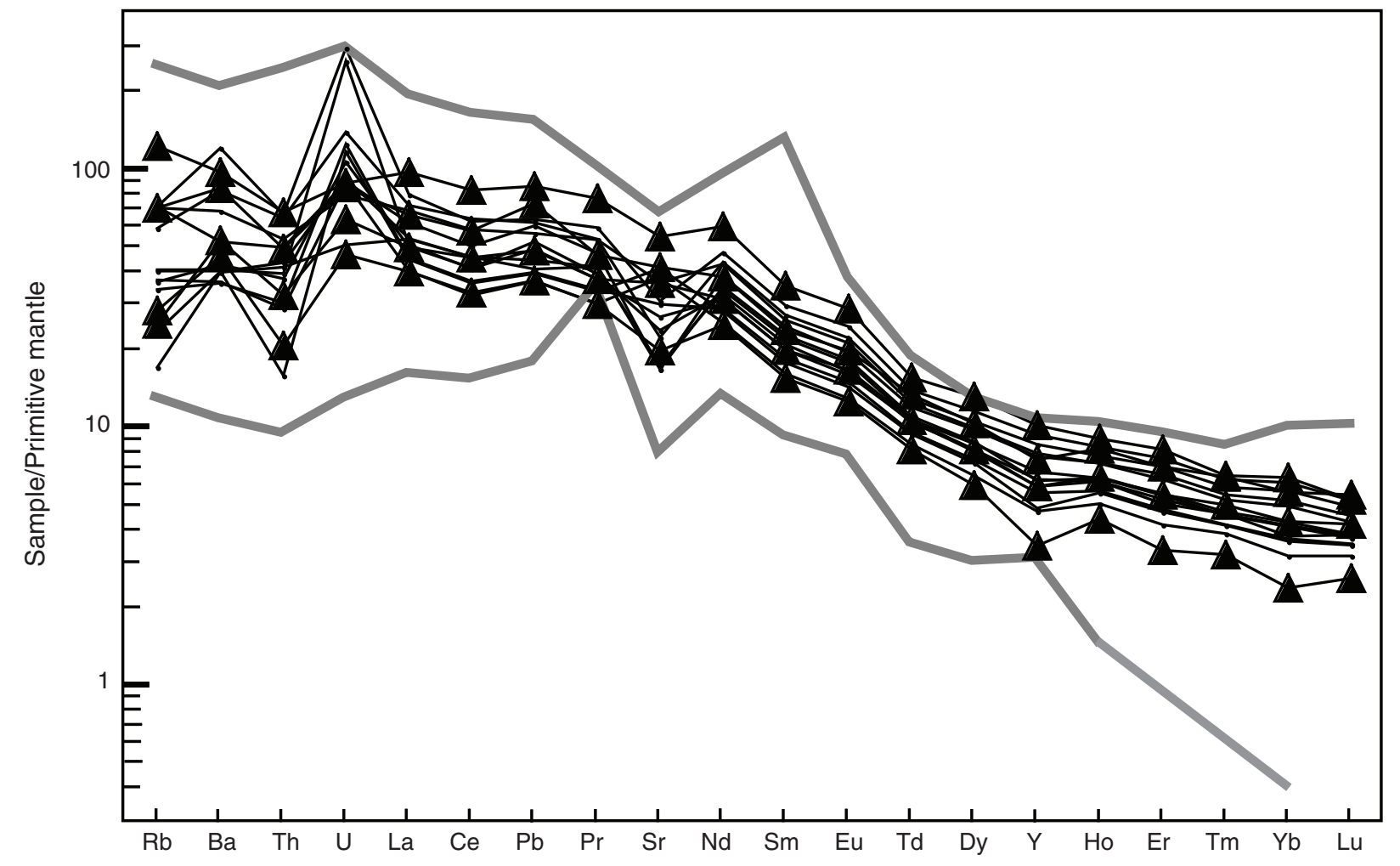


Figure F3. Plot of $\mathrm{Ba}, \mathrm{La}, \mathrm{Ba} / \mathrm{La}$, and organic carbon contents of the volcaniclastic sediments vs. depth, Hole M0008A.

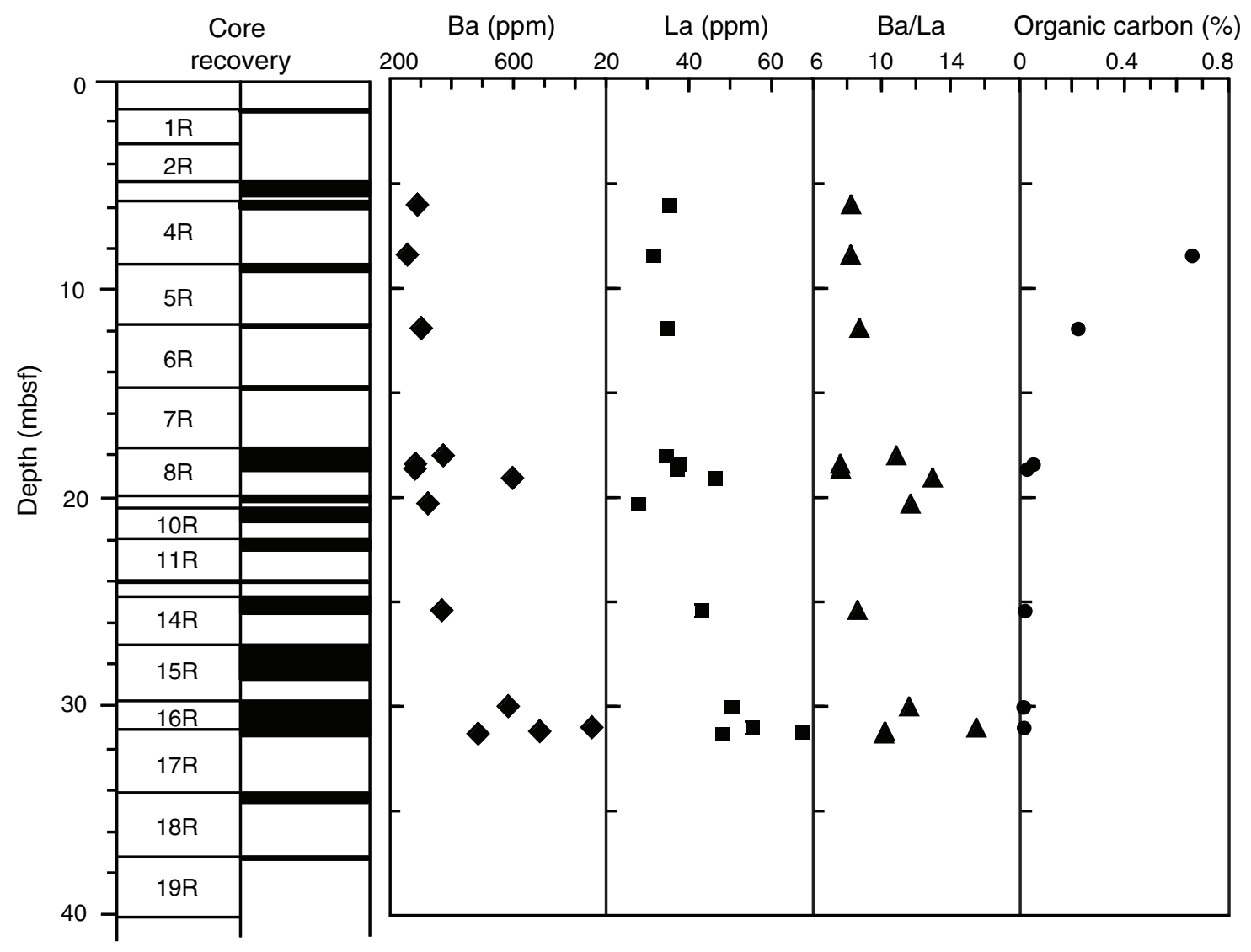


Table T1. Major and trace element analyses of volcaniclastic sediments. (See table notes.) (Continued on next three pages.)

\begin{tabular}{|c|c|c|c|c|c|c|}
\hline $\begin{array}{l}\text { Core, section: } \\
\text { Interval }(\mathrm{cm}) \text { : }\end{array}$ & $\begin{array}{l}\text { 310-M0008A-4R-1 } \\
\quad 22-28\end{array}$ & $\begin{array}{l}\text { 310-M0008A-5R-1 } \\
15-20\end{array}$ & $\begin{array}{l}\text { 310-M0008A-6R-1 } \\
\quad 5-9\end{array}$ & $\begin{array}{c}\text { 310-M0008A-7R-CC } \\
4-13\end{array}$ & $\begin{array}{l}\text { 310-M0008A-8R-1 } \\
\quad 42-51\end{array}$ & $\begin{array}{c}\text { 310-M0008A-8R-1 } \\
61-80\end{array}$ \\
\hline Sample & Gray sand/silt & Gray sand/silt & Gray sand/silt & Boulder & Boulder & Cobble \\
\hline \multicolumn{7}{|c|}{ Major element oxides (wt\%) } \\
\hline $\mathrm{SiO}_{2}$ & 32.79 & 29.86 & 40.32 & 42.15 & 42.68 & 42.32 \\
\hline $\mathrm{TiO}_{2}$ & 2.97 & 2.83 & 3.66 & 3.15 & 3.13 & 1.77 \\
\hline $\mathrm{Al}_{2} \mathrm{O}_{3}$ & 13.22 & 11.92 & 11.67 & 15.56 & 15.83 & 8.51 \\
\hline $\mathrm{FeO}^{*}$ & 11.72 & 10.91 & 12.82 & 10.94 & 11.03 & 9.75 \\
\hline $\mathrm{MnO}$ & 0.15 & 0.14 & 0.17 & 0.16 & 0.17 & 0.17 \\
\hline $\mathrm{MgO}$ & 9.99 & 9.67 & 10.44 & 4.98 & 6.04 & 16.76 \\
\hline $\mathrm{CaO}$ & 7.63 & 9.12 & 10.15 & 9.58 & 9.98 & 12.02 \\
\hline $\mathrm{Na}_{2} \mathrm{O}$ & 1.98 & 1.79 & 2.16 & 1.79 & 2.65 & 1.21 \\
\hline $\mathrm{K}_{2} \mathrm{O}$ & 0.81 & 0.71 & 1.11 & 1.21 & 1.07 & 0.44 \\
\hline $\mathrm{P}_{2} \mathrm{O}_{5}$ & 0.30 & 0.26 & 0.36 & 0.69 & 0.66 & 0.14 \\
\hline LOI & 10.36 & 11.56 & 6.45 & 1.90 & 2.18 & 1.88 \\
\hline \multicolumn{7}{|c|}{ Trace elements by XRF (ppm) } \\
\hline $\mathrm{Ni}$ & 241 & 248 & 244 & 50.9 & 54.1 & 381 \\
\hline $\mathrm{Cr}$ & & & 732 & & & \\
\hline Sc & & & 30 & & & \\
\hline V & & & 327 & & & \\
\hline $\mathrm{Ba}$ & 100 & 211 & 282 & 398 & 319 & 125 \\
\hline $\mathrm{Rb}$ & 23.2 & 21.4 & 24 & 22.8 & 22.5 & 11.1 \\
\hline $\mathrm{Sr}$ & 432 & 544 & 473 & 675 & 662 & 258 \\
\hline $\mathrm{Zr}$ & & & 262 & & & \\
\hline $\mathrm{Y}$ & & & 25 & & & \\
\hline $\mathrm{Nb}$ & & & 38.7 & & & \\
\hline $\mathrm{Ga}$ & & & 18 & & & \\
\hline $\mathrm{Cu}$ & 54.1 & 61.2 & 58 & 93.9 & 88.2 & 45.2 \\
\hline $\mathrm{Zn}$ & 104 & 97 & 127 & 95 & 94 & 68 \\
\hline $\mathrm{Pb}$ & & & 2 & & & \\
\hline La & & & 36 & & & \\
\hline $\mathrm{Ce}$ & & & 62 & & & \\
\hline Th & & & 2 & & & \\
\hline $\mathrm{Nd}$ & & & 35 & & & \\
\hline $\mathrm{U}$ & & & 5 & & & \\
\hline \multicolumn{7}{|c|}{ Trace elements by ICP-MS (ppm) } \\
\hline $\mathrm{Rb}$ & 26.1 & 21.9 & 23.4 & 9.6 & 16.0 & 4.5 \\
\hline $\mathrm{Sr}$ & 570 & 636 & 504 & 365 & 770 & 185 \\
\hline $\mathrm{Y}$ & 26.9 & 25.4 & 28.6 & 4.9 & 26.9 & 7.1 \\
\hline $\mathrm{Ba}$ & 288 & 255 & 300 & 258 & 372 & 97 \\
\hline La & 35.11 & 31.26 & 34.52 & 4.53 & 34.34 & 6.00 \\
\hline $\mathrm{Ce}$ & 73.83 & 65.87 & 73.95 & 44.67 & 81.04 & 18.46 \\
\hline $\mathrm{Pr}$ & 10.41 & 9.51 & 10.87 & 1.35 & 10.40 & 2.02 \\
\hline $\mathrm{Nd}$ & 42.61 & 39.18 & 44.45 & 5.82 & 42.65 & 9.23 \\
\hline $\mathrm{Sm}$ & 8.88 & 8.26 & 9.34 & 1.17 & 8.90 & 1.96 \\
\hline $\mathrm{Eu}$ & 2.69 & 2.53 & 2.77 & 0.36 & 2.81 & 0.53 \\
\hline $\mathrm{Tb}$ & 1.15 & 1.04 & 1.13 & - & 1.16 & - \\
\hline Dy & 5.98 & 5.55 & 6.08 & 0.94 & 6.06 & 1.57 \\
\hline Ho & 1.02 & 0.93 & 1.02 & - & 1.06 & - \\
\hline $\mathrm{Er}$ & 2.44 & 2.32 & 2.53 & 0.31 & 2.64 & 0.48 \\
\hline $\mathrm{Tm}$ & 0.34 & 0.31 & 0.34 & - & 0.37 & - \\
\hline $\mathrm{Yb}$ & 1.87 & 1.83 & 2.07 & 0.15 & 2.13 & 0.21 \\
\hline Lu & 0.29 & 0.26 & 0.28 & - & 0.31 & - \\
\hline $\mathrm{Pb}$ & 3.5 & 2.8 & 3.7 & 5.4 & 3.5 & 2.0 \\
\hline Th & 3.4 & 2.6 & 3.2 & 0.5 & 2.8 & 0.4 \\
\hline U & 5.5 & 2.6 & 2.3 & 1.3 & 1.3 & 0.4 \\
\hline $\mathrm{La} / \mathrm{Sm}_{\mathrm{N}}$ & 2.55 & 2.45 & 2.39 & 2.51 & 2.49 & 1.98 \\
\hline \multicolumn{7}{|l|}{ Carbon (wt\%) } \\
\hline Total & 1.00 & 1.36 & 0.37 & & & \\
\hline Organic & 0.68 & 0.66 & 0.22 & & & \\
\hline Inorganic & 0.33 & 0.70 & 0.15 & & & \\
\hline
\end{tabular}


Table T1 (continued). (Continued on next page.)

\begin{tabular}{|c|c|c|c|c|c|c|c|}
\hline $\begin{array}{l}\text { Core, section: } \\
\text { Interval }(\mathrm{cm}) \text { : }\end{array}$ & $\begin{array}{l}\text { 310-M0008A-8R-1 } \\
84-89\end{array}$ & Duplicate & $\begin{array}{c}\text { 310-M0008A-8R-1 } \\
107-111\end{array}$ & Duplicate & $\begin{array}{c}\text { 310-M0008A-9R-CC } \\
0-5\end{array}$ & $\begin{array}{c}\text { 310-M0008A-10R-1 } \\
27-30\end{array}$ & $\begin{array}{c}310-\mathrm{M} 0008 \mathrm{~A}-14 \mathrm{R}-1 \\
0-10\end{array}$ \\
\hline Sample & Gray sand/silt & & Brown sand/silt & & Pebble & Pebble & Pebble \\
\hline \multicolumn{8}{|c|}{ Major element oxides (wt\%) } \\
\hline $\mathrm{SiO}_{2}$ & 41.23 & 41.42 & 41.26 & & 41.01 & 37.80 & 44.03 \\
\hline $\mathrm{TiO}_{2}$ & 3.95 & 3.97 & 3.86 & & 3.46 & 2.90 & 4.07 \\
\hline $\mathrm{Al}_{2} \mathrm{O}_{3}$ & 10.97 & 11.06 & 11.27 & & 15.87 & 9.69 & 16.50 \\
\hline $\mathrm{FeO}^{*}$ & 14.71 & 14.57 & 14.55 & & 11.14 & 11.61 & 9.29 \\
\hline $\mathrm{MnO}$ & 0.15 & 0.15 & 0.15 & & 0.18 & 0.17 & 0.13 \\
\hline $\mathrm{MgO}$ & 10.82 & 10.90 & 11.57 & & 4.33 & 14.22 & 3.07 \\
\hline $\mathrm{CaO}$ & 6.17 & 6.21 & 6.84 & & 8.96 & 9.12 & 8.89 \\
\hline $\mathrm{Na}_{2} \mathrm{O}$ & 2.02 & 2.00 & 1.72 & & 3.19 & 1.56 & 2.14 \\
\hline $\mathrm{K}_{2} \mathrm{O}$ & 0.96 & 0.96 & 0.77 & & 1.45 & 0.95 & 2.01 \\
\hline $\mathrm{P}_{2} \mathrm{O}_{5}$ & 0.29 & 0.29 & 0.31 & & 0.51 & 0.25 & 0.90 \\
\hline LOI & 8.22 & 8.22 & 7.46 & 7.35 & 3.83 & 9.74 & 5.77 \\
\hline \multicolumn{8}{|c|}{ Trace elements by XRF (ppm) } \\
\hline $\mathrm{Ni}$ & 403 & 405 & 448 & & 66.1 & 453 & 90.9 \\
\hline $\mathrm{Cr}$ & 862 & 875 & 778 & & & & \\
\hline Sc & 32 & 31 & 32 & & & & \\
\hline V & 320 & 326 & 308 & & & & \\
\hline $\mathrm{Ba}$ & 256 & 256 & 255 & & 503 & 320 & 750 \\
\hline $\mathrm{Rb}$ & 18 & 18 & 14 & & 30.9 & 23.2 & 40.1 \\
\hline $\mathrm{Sr}$ & 307 & 304 & 323 & & 646 & 414 & 754 \\
\hline $\mathrm{Zr}$ & 242 & 236 & 246 & & & & \\
\hline$Y$ & 23 & 24 & 25 & & & & \\
\hline $\mathrm{Nb}$ & 40.8 & 40.3 & 42.4 & & & & \\
\hline $\mathrm{Ga}$ & 18 & 19 & 19 & & & & \\
\hline $\mathrm{Cu}$ & 65 & 64 & 52 & & 113 & 67.8 & 51.1 \\
\hline $\mathrm{Zn}$ & 145 & 147 & 129 & & 99 & 98 & 89 \\
\hline $\mathrm{Pb}$ & 1 & 3 & 2 & & & & \\
\hline $\mathrm{La}$ & 35 & 34 & 37 & & & & \\
\hline $\mathrm{Ce}$ & 63 & 68 & 66 & & & & \\
\hline Th & 3 & 9 & 3 & & & & \\
\hline $\mathrm{Nd}$ & 35 & 37 & 39 & & & & \\
\hline $\mathrm{U}$ & 2 & 1 & 1 & & & & \\
\hline \multicolumn{8}{|c|}{ Trace elements by ICP-MS (ppm) } \\
\hline $\mathrm{Rb}$ & 15.0 & & 10.9 & & 45.3 & 18.1 & 17.5 \\
\hline $\mathrm{Sr}$ & 369 & & 357 & & 887 & 419 & 612 \\
\hline $\mathrm{Y}$ & 30.8 & & 28.4 & & 34.1 & 15.9 & 12.0 \\
\hline $\mathrm{Ba}$ & 282 & & 281 & & 595 & 323 & 648 \\
\hline $\mathrm{La}$ & 37.34 & & 36.98 & & 45.96 & 27.65 & 14.13 \\
\hline $\mathrm{Ce}$ & 81.74 & & 81.42 & & 103.00 & 59.17 & 31.86 \\
\hline $\operatorname{Pr}$ & 11.56 & & 11.62 & & 12.88 & 8.34 & 4.40 \\
\hline $\mathrm{Nd}$ & 46.34 & & 47.60 & & 52.13 & 33.87 & 18.43 \\
\hline Sm & 9.83 & & 10.11 & & 10.62 & 6.93 & 3.78 \\
\hline Eu & 3.00 & & 3.09 & & 3.35 & 2.12 & 1.24 \\
\hline $\mathrm{Tb}$ & 1.17 & & 1.19 & & 1.45 & 0.89 & 0.62 \\
\hline Dy & 6.38 & & 6.50 & & 7.66 & 4.41 & 2.50 \\
\hline Ho & 1.05 & & 1.05 & & 1.36 & 0.73 & - \\
\hline $\mathrm{Er}$ & 2.67 & & 2.62 & & 3.39 & 1.61 & 0.90 \\
\hline $\mathrm{Tm}$ & 0.35 & & 0.34 & & 0.48 & 0.24 & - \\
\hline $\mathrm{Yb}$ & 2.12 & & 2.04 & & 2.78 & 1.18 & 0.58 \\
\hline $\mathrm{Lu}$ & 0.29 & & 0.28 & & 0.41 & 0.19 & - \\
\hline $\mathrm{Pb}$ & 3.2 & & 2.9 & & 5.3 & 2.6 & 5.5 \\
\hline Th & 3.7 & & 3.6 & & 4.2 & 1.8 & 1.5 \\
\hline U & 1.9 & & 1.1 & & 1.8 & 1.0 & 1.0 \\
\hline $\mathrm{La} / \mathrm{Sm}_{\mathrm{N}}$ & 2.45 & & 2.36 & & 2.80 & 2.58 & 2.42 \\
\hline \multicolumn{8}{|l|}{ Carbon (wt\%) } \\
\hline Total & 0.07 & & 0.03 & 0.03 & & & \\
\hline Organic & 0.05 & & 0.02 & 0.02 & & & \\
\hline Inorganic & 0.02 & & 0.01 & 0.01 & & & \\
\hline
\end{tabular}


Table T1 (continued). (Continued on next page.)

\begin{tabular}{|c|c|c|c|c|c|c|c|}
\hline $\begin{array}{l}\text { Core, section: } \\
\text { Interval }(\mathrm{cm}) \text { : }\end{array}$ & $\begin{array}{c}310-\mathrm{M} 0008 \mathrm{~A}-14 \mathrm{R}-1 \\
24-28\end{array}$ & $\begin{array}{c}\text { 310-M0008A-16R-1 } \\
55-60\end{array}$ & $\begin{array}{c}\text { 310-M0008A-16R-1 } \\
115-120\end{array}$ & $\begin{array}{c}\text { 310-M0008A-17R-1 } \\
0-5\end{array}$ & $\begin{array}{c}\text { 310-M0008A-17R-1 } \\
10-15\end{array}$ & $\begin{array}{c}\text { 310-M0008A-17R-1 } \\
18-23\end{array}$ & $\begin{array}{c}310-\mathrm{M} 00010 \mathrm{~A}-1 \mathrm{R}-1 \\
22-26\end{array}$ \\
\hline Sample & Brown sand/silt & Brown sand/silt & Brown clay/sand & Pebble & Pebble & Pebble & Gray sand \\
\hline \multicolumn{8}{|c|}{ Major element oxides (wt\%) } \\
\hline $\mathrm{SiO}_{2}$ & 41.44 & 38.90 & 31.37 & 43.59 & 45.15 & 47.06 & 37.88 \\
\hline $\mathrm{TiO}_{2}$ & 3.22 & 3.39 & 3.84 & 3.33 & 3.69 & 3.64 & 2.91 \\
\hline $\mathrm{Al}_{2} \mathrm{O}_{3}$ & 12.04 & 14.80 & 13.88 & 14.85 & 14.96 & 16.66 & 11.12 \\
\hline $\mathrm{FeO}^{*}$ & 14.20 & 14.44 & 14.93 & 10.96 & 10.51 & 10.25 & 11.06 \\
\hline $\mathrm{MnO}$ & 0.16 & 0.21 & 0.36 & 0.15 & 0.16 & 0.16 & 0.14 \\
\hline $\mathrm{MgO}$ & 4.96 & 5.15 & 2.95 & 5.59 & 4.48 & 5.08 & 10.50 \\
\hline $\mathrm{CaO}$ & 1.36 & 1.60 & 1.44 & 9.37 & 7.63 & 9.98 & 12.77 \\
\hline $\mathrm{Na}_{2} \mathrm{O}$ & 1.91 & 1.97 & 2.02 & 1.57 & 3.36 & 2.46 & 2.14 \\
\hline $\mathrm{K}_{2} \mathrm{O}$ & 0.73 & 0.76 & 0.84 & 1.48 & 2.04 & 1.81 & 1.01 \\
\hline $\mathrm{P}_{2} \mathrm{O}_{5}$ & 0.05 & 0.23 & 0.32 & 0.58 & 0.88 & 0.88 & 0.32 \\
\hline LOI & 21.07 & 16.98 & 21.72 & 2.13 & 2.38 & 1.37 & 10.30 \\
\hline \multicolumn{8}{|c|}{ Trace elements by XRF (ppm) } \\
\hline $\mathrm{Ni}$ & 230 & 305 & 286 & 100 & 30.8 & 73.3 & 243 \\
\hline $\mathrm{Cr}$ & & & & & & & 646 \\
\hline Sc & & & & & & & 29 \\
\hline $\mathrm{V}$ & & & & & & & 266 \\
\hline $\mathrm{Ba}$ & 288 & 279 & 324 & 361 & 523 & 480 & 262 \\
\hline $\mathrm{Rb}$ & 35.8 & 29.6 & 37.5 & 31.2 & 56.8 & 40.5 & 22 \\
\hline $\mathrm{Sr}$ & 287 & 370 & 422 & 609 & 808 & 722 & 782 \\
\hline $\mathrm{Zr}$ & & & & & & & 223 \\
\hline$Y$ & & & & & & & 21 \\
\hline $\mathrm{Nb}$ & & & & & & & 33.7 \\
\hline Ga & & & & & & & 17 \\
\hline $\mathrm{Cu}$ & 51.3 & 66.0 & 70.6 & 69.1 & 72.7 & 69.0 & 43 \\
\hline $\mathrm{Zn}$ & 113 & 124 & 122 & 103 & 120 & 116 & 103 \\
\hline $\mathrm{Pb}$ & & & & & & & 1 \\
\hline La & & & & & & & 31 \\
\hline $\mathrm{Ce}$ & & & & & & & 60 \\
\hline Th & & & & & & & 2 \\
\hline $\mathrm{Nd}$ & & & & & & & 33 \\
\hline $\mathrm{U}$ & & & & & & & 3 \\
\hline \multicolumn{8}{|c|}{ Trace elements by ICP-MS (ppm) } \\
\hline $\mathrm{Rb}$ & 45.9 & 37.7 & 45.7 & 13.4 & 78.6 & 45.1 & 23.8 \\
\hline $\mathrm{Sr}$ & 357 & 474 & 656 & 281 & 1166 & 773 & 803 \\
\hline Y & 35.2 & 39.2 & 42.7 & 8.0 & 46.6 & 36.3 & 21.5 \\
\hline $\mathrm{Ba}$ & 367 & 581 & 852 & 192 & 684 & 484 & 258 \\
\hline La & 42.93 & 50.21 & 55.05 & 9.22 & 67.17 & 47.85 & 27.81 \\
\hline $\mathrm{Ce}$ & 89.93 & 114.58 & 112.55 & 21.13 & 148.39 & 104.19 & 57.87 \\
\hline $\operatorname{Pr}$ & 13.12 & 14.92 & 16.51 & 2.70 & 21.42 & 14.77 & 8.38 \\
\hline $\mathrm{Nd}$ & 52.45 & 59.42 & 64.94 & 11.24 & 81.78 & 58.43 & 34.56 \\
\hline Sm & 11.00 & 12.14 & 13.23 & 2.28 & 15.83 & 11.65 & 7.20 \\
\hline $\mathrm{Eu}$ & 3.29 & 3.76 & 4.14 & 0.65 & 4.87 & 3.59 & 2.18 \\
\hline $\mathrm{Tb}$ & 1.29 & 1.40 & 1.51 & 0.45 & 1.70 & 1.34 & 0.93 \\
\hline Dy & 7.24 & 7.79 & 8.55 & 1.56 & 9.75 & 7.39 & 4.80 \\
\hline Ho & 1.20 & 1.28 & 1.38 & 0.35 & 1.49 & 1.19 & 0.83 \\
\hline Er & 3.16 & 3.40 & 3.66 & 0.54 & 3.95 & 3.03 & 2.03 \\
\hline $\mathrm{Tm}$ & 0.41 & 0.44 & 0.47 & - & 0.48 & 0.39 & 0.29 \\
\hline $\mathrm{Yb}$ & 2.58 & 2.81 & 3.03 & 0.33 & 3.17 & 2.44 & 1.57 \\
\hline Lu & 0.34 & 0.37 & 0.39 & - & 0.39 & 0.32 & 0.24 \\
\hline $\mathrm{Pb}$ & 4.3 & 4.4 & 4.6 & 3.8 & 6.2 & 4.0 & 2.6 \\
\hline Th & 4.3 & 5.5 & 5.7 & 1.2 & 5.8 & 4.6 & 2.5 \\
\hline$U$ & 1.9 & 2.9 & 6.2 & 1.4 & 1.9 & 1.7 & 1.9 \\
\hline $\mathrm{La} / \mathrm{Sm}_{\mathrm{N}}$ & 2.52 & 2.67 & 2.69 & 2.62 & 2.74 & 2.66 & 2.50 \\
\hline \multicolumn{8}{|l|}{ Carbon (wt\%) } \\
\hline Total & 0.01 & 0.03 & 0.01 & & & & 1.20 \\
\hline Organic & 0.01 & 0.01 & 0.01 & & & & 0.19 \\
\hline Inorganic & 0.00 & 0.02 & 0.00 & & & & 1.01 \\
\hline
\end{tabular}


Table T1 (continued).

\begin{tabular}{|c|c|c|c|c|c|c|}
\hline $\begin{array}{l}\text { Core, section: } \\
\text { Interval }(\mathrm{cm}) \text { : }\end{array}$ & $\begin{array}{c}\text { 310-M0010A-2R-1 } \\
23-27\end{array}$ & $\begin{array}{c}\text { 310-M0021B-18R-1 } \\
32-33\end{array}$ & $\begin{array}{c}\text { 310-M0021B-18R-1 } \\
55-58\end{array}$ & $\begin{array}{c}\text { 310-M0021B-19R-1 } \\
11-13\end{array}$ & $\begin{array}{c}\text { 310-M0021B-20R-1 } \\
83-85\end{array}$ & $\begin{array}{c}\text { 310-M0021B-20R-1 } \\
116-118\end{array}$ \\
\hline Sample & Gray sand & Gray sand & Calcareous sand & Gray sand & Light brown sand & Light brown sand \\
\hline \multicolumn{7}{|c|}{ Major element oxides (wt\%) } \\
\hline $\mathrm{SiO}_{2}$ & 38.12 & & 7.91 & & & \\
\hline $\mathrm{TiO}_{2}$ & 3.10 & & 0.79 & & & \\
\hline $\mathrm{Al}_{2} \mathrm{O}_{3}$ & 11.04 & & 2.41 & & & \\
\hline $\mathrm{FeO}^{*}$ & 11.22 & & 2.77 & & & \\
\hline $\mathrm{MnO}$ & 0.15 & & 0.04 & & & \\
\hline $\mathrm{MgO}$ & 10.20 & & 5.07 & & & \\
\hline $\mathrm{CaO}$ & 12.82 & & 43.23 & & & \\
\hline $\mathrm{Na}_{2} \mathrm{O}$ & 2.13 & & 0.62 & & & \\
\hline $\mathrm{K}_{2} \mathrm{O}$ & 1.02 & & 0.22 & & & \\
\hline $\mathrm{P}_{2} \mathrm{O}_{5}$ & 0.32 & & 0.13 & & & \\
\hline LOI & 9.42 & 35.23 & 36.92 & 25.75 & 16.98 & 22.10 \\
\hline \multicolumn{7}{|c|}{ Trace elements by XRF (ppm) } \\
\hline $\mathrm{Ni}$ & 230 & & 47 & & & \\
\hline $\mathrm{Cr}$ & 656 & & 140 & & & \\
\hline Sc & 30 & & 7 & & & \\
\hline $\mathrm{V}$ & 277 & & 74 & & & \\
\hline $\mathrm{Ba}$ & 260 & & 49 & & & \\
\hline $\mathrm{Rb}$ & 23 & & 9 & & & \\
\hline $\mathrm{Sr}$ & 751 & & 3571 & & & \\
\hline $\mathrm{Zr}$ & 232 & & 68 & & & \\
\hline $\mathrm{Y}$ & 21 & & 5 & & & \\
\hline $\mathrm{Nb}$ & 34.1 & & 9.6 & & & \\
\hline $\mathrm{Ga}$ & 16 & & 3 & & & \\
\hline $\mathrm{Cu}$ & 44 & & 14 & & & \\
\hline $\mathrm{Zn}$ & 106 & & 26 & & & \\
\hline $\mathrm{Pb}$ & 1 & & 1 & & & \\
\hline La & 28 & & 1 & & & \\
\hline $\mathrm{Ce}$ & 54 & & 7 & & & \\
\hline Th & 2 & & 5 & & & \\
\hline $\mathrm{Nd}$ & 33 & & 7 & & & \\
\hline U & 3 & & 3 & & & \\
\hline \multicolumn{7}{|c|}{ Trace elements by ICP-MS (ppm) } \\
\hline $\mathrm{Rb}$ & 25.7 & 7.8 & 4.8 & 10.5 & 13.2 & 14.7 \\
\hline $\mathrm{Sr}$ & 877 & 1893 & 2238 & 1435 & 580 & 751 \\
\hline Y & 22.2 & 3.4 & 4.2 & 4.6 & 9.8 & 11.2 \\
\hline $\mathrm{Ba}$ & 283 & 20 & 26 & 38 & 98 & 126 \\
\hline La & 30.82 & 2.82 & 3.34 & 4.95 & 11.21 & 10.64 \\
\hline $\mathrm{Ce}$ & 64.49 & 5.98 & 7.12 & 10.47 & 24.77 & 23.92 \\
\hline $\operatorname{Pr}$ & 9.34 & 0.84 & 1.00 & 1.46 & 3.37 & 3.20 \\
\hline $\mathrm{Nd}$ & 38.47 & 3.87 & 4.50 & 6.33 & 14.04 & 13.53 \\
\hline $\mathrm{Sm}$ & 7.96 & 0.74 & 0.90 & 1.23 & 2.81 & 2.89 \\
\hline $\mathrm{Eu}$ & 2.42 & 0.14 & 0.21 & 0.28 & 0.78 & 0.84 \\
\hline $\mathrm{Tb}$ & 1.02 & - & - & - & 0.52 & 0.54 \\
\hline Dy & 5.40 & 0.65 & 0.77 & 0.95 & 1.99 & 2.10 \\
\hline Ho & 0.92 & - & - & - & - & - \\
\hline $\mathrm{Er}$ & 2.26 & 0.12 & 0.20 & 0.24 & 0.72 & 0.77 \\
\hline $\mathrm{Tm}$ & 0.31 & - & - & - & - & - \\
\hline $\mathrm{Yb}$ & 1.79 & - & 0.02 & 0.04 & 0.46 & 0.52 \\
\hline Lu & 0.26 & - & - & - & - & - \\
\hline $\mathrm{Pb}$ & 2.8 & 0.8 & 0.7 & 1.5 & 2.1 & 2.1 \\
\hline Th & 1.4 & 0.5 & 0.5 & 0.5 & 1.5 & 1.5 \\
\hline u & 2.5 & 2.2 & 1.7 & 1.9 & 2.0 & 2.6 \\
\hline $\mathrm{La} / \mathrm{Sm}_{\mathrm{N}}$ & 2.50 & 2.46 & 2.39 & 2.59 & 2.58 & 2.38 \\
\hline \multicolumn{7}{|l|}{ Carbon (wt\%) } \\
\hline Total & 1.23 & 11.46 & 5.99 & 7.31 & 3.83 & 4.18 \\
\hline Organic & 0.17 & 0.20 & 0.96 & 0.19 & 0.05 & 0.13 \\
\hline Inorganic & 1.06 & 11.26 & 5.02 & 7.12 & 3.78 & 4.05 \\
\hline
\end{tabular}

Notes: $\mathrm{LOI}=$ loss on ignition, $\mathrm{XRF}=\mathrm{X}$-ray diffraction, ICP-MS $=$ inductively coupled-mass spectrometry. $-=$ below detection limit, empty cells $=$ not analyzed. 
Table T2. Clast ages.

\begin{tabular}{|c|c|c|c|c|}
\hline $\begin{array}{l}\text { Hole, core, section, interval } \\
\qquad(\mathrm{cm})\end{array}$ & $\begin{array}{l}\text { Clast } \\
\text { type }\end{array}$ & $\begin{array}{l}\text { Data } \\
\text { type }\end{array}$ & $\begin{array}{l}\text { Age } \\
(\mathrm{Ma})\end{array}$ & $\stackrel{ \pm}{(\mathrm{Ma})}$ \\
\hline \multicolumn{5}{|l|}{$310-$} \\
\hline M0008A-7R-CC, 4-13 cm & Boulder & Weighted plateau & 0.66 & 0.03 \\
\hline M0008A-8R-1, 42-51 cm & Boulder & Weighted plateau & 0.69 & 0.03 \\
\hline M0008A-17R-1, $18-23 \mathrm{~cm}$ & Pebble & Normal isochron & 0.64 & 0.06 \\
\hline M0010A-20R-1, 8-14 cm & Pebble & Weighted plateau & 0.33 & 0.04 \\
\hline
\end{tabular}

